\title{
Improving SWAT for simulating water and carbon fluxes of forest ecosystems
}

\author{
Qichun Yang; Xuesong Zhang*a,b
}

a) Joint Global Change Research Institute, Pacific Northwest National Lab, College Park, Maryland 20740, USA

b) Great Lakes Bioenergy Research Center, Michigan State University, East Lansing, Michigan 48824, USA

*Corresponding author

Tel: +1 301-314-6706; Fax: +1 301-314-6719

Email: xuesong.zhang@pnnl.gov

June 2016

Submitted to Science of the Total Environment 


\begin{abstract}
As a widely used watershed model for assessing impacts of anthropogenic and natural disturbances on water quantity and quality, the Soil and Water Assessment Tool (SWAT) has not been extensively tested in simulating water and carbon fluxes of forest ecosystems. Here, we examine SWAT simulations of evapotranspiration (ET), net primary productivity (NPP), net ecosystem exchange (NEE), and plant biomass at ten AmeriFlux forest sites across the U.S. We identify unrealistic radiation use efficiency (Bio_E), large leaf to biomass fraction (Bio_LEAF), and missing phosphorus supply from parent material weathering as the primary causes for the inadequate performance of the default SWAT model in simulating forest dynamics. By further revising the relevant parameters and processes, SWAT's performance is substantially improved. Based on the comparison between the improved SWAT simulations and flux tower observations, we discuss future research directions for further enhancing model parameterization and representation of water and carbon cycling for forests.
\end{abstract}

Key words: Forest; Carbon; Water; Phosphorus; Parameterization 


\section{Introduction}

Carbon cycling is closely coupled with water and nutrient cycling in ecosystems, thus should be considered in explaining hydrological and biogeochemical dynamics (Bosch and Hewlett, 1982; Canton et al., 2010). For example, negative relationships between percentage of forest cover and stream flows were reported (Brown et al., 2005) and attributed to the high water consumption through evapotranspiration (ET) by trees. Removal of vegetation biomass could increase water yield as a result of ET reduction (Bosch and Hewlett, 1982). Previous studies also underscored the impacts of plant growth and management on riverine nutrient fluxes since carbon and nutrients are closely connected via processes such as nutrient uptake, carbon allocation, litter and soil organic matter decomposition (Briggs et al., 2000; Niinemets and Tamm, 2005). Therefore, accurate representation of the complex interplays between carbon, nutrient, and water cycles is essential for reliable understanding of ecosystem dynamics and responses to changes in environmental controls.

Forests have significant influences on global carbon, water, and nutrient cycling. Due to high biomass density, forests play a disproportionately important role in the global carbon cycle. It was estimated that nearly $80 \%$ of the terrestrial above ground carbon is stored in forests (Dixon et al., 1994). Carbon exchange between the atmosphere and forests has been a hot spot in global carbon cycling investigations since this carbon flux affects the atmospheric $\mathrm{CO}_{2}$ concentrations. High water consumption by trees makes forests an important component of the global hydrological cycle (Aragão, 2012). In addition, forests affect nutrient cycling through the close coupling between carbon and nutrient fluxes in ecosystems (Aust and Blinn, 2004). Forest biomass could hold up to $28 \%$ and $38 \%$ of total ecosystem nitrogen $(\mathrm{N})$ and phosphorus $(\mathrm{P})$, respectively (Hart et al., 2003). Nutrient uptake from soils to plant biomass and subsequent 
return to forest floors through litter fall contribute to the seasonal variability in riverine nutrient export (Mulholland and Hill, 1997).

Numerous numerical models have been developed and applied to investigate the interplays of carbon, water, and nutrients in terrestrial ecosystems (Delire and Foley, 1999; Entekhabi and Eagleson, 1989). Model simulation experiments are useful tools in disentangling the complex interactions among plant physiology, water cycling, and nutrient cycling (Yang et al., 2015). Among these models, the Soil and Water Assessment Tool (SWAT, Arnold et al., 1998) model has been widely applied to assess impacts of anthropogenic activities and climate change on biogeochemical cycling (El-Khoury et al., 2015), hydrological dynamics (Leta et al., 2015; Faramarzi et al., 2015) and environmental pollutions ( Baffaut et al., 2015; Holvoet et al., 2008) at watershed or regional scales. As of December 31, 2015, over 2,300 peer reviewed journal articles have reviewed or examined SWAT (or its components) in watersheds around the globe (https://www.card.iastate.edu/swat_articles/). Currently, SWAT is a key component of the USDA-Conservation Effect Assessment Project (CEAP) (Arnold et al., 2010) and the USEPAHydrologic And Water Quality System (HAWQS) (epahawqs.tamu.edu).

Most of the previous studies using SWAT mainly focused on agricultural ecosystems (Zhang et al., 2013), and few studies have examined the performance of SWAT in forest ecosystems. To the best of the authors' knowledge, the current literature database of the SWAT model does not include a publication testing and evaluating SWAT simulations of carbon and water fluxes of forest ecosystems using long-term in-situ measurements at the site scale. As forests often cover a significant portion of land in most watersheds (Jin et al., 2013), the insufficient test and examination of SWAT in forest ecosystems represent an inadequately addressed uncertainty in the application of SWAT as a watershed model. Given the important 
role of forests in carbon, nutrient, and water cycling, there is an urgent need to evaluate SWAT's capability in modeling forest ecosystems for future model application and improvement.

In this study, we examine and evaluate SWAT simulations of carbon and water fluxes against flux tower observations at ten AmeriFlux forest sites across the United States (U.S.). In doing so, we diagnose strengths and deficiencies of SWAT and revise relevant parameters and processes for modeling forest ecosystem, based on which we analyze and discuss future directions of improving model parameterization and carbon cycling representation. This work is expected to help design effective procedures to ensure the robust application of SWAT for simulating the complex interplays among forest physiology, water cycling, and biogeochemical cycling in watersheds containing both cropland and forest, thus help enhance the model's capability in assessing impacts of multiple environment changes on water resources, environment quality, and ecosystem integrity.

\section{Materials and Methods}

\subsection{Data collection}

[Fig. 1]

[Table 1]

We collected field data from ten U.S. AmeriFlux sites, including Harvard Forest (US-Ha1), Howland Forest Main (US-Ho1), Morgan Monroe State Forest (US-MMS), Missouri Ozark (USMOz), Sylvania Wilderness (US-Syv), UMBS (US-UMB), Walker Branch (US-WBW), Willow Creek forest (US-WCr), Niwot Ridge (US-NR1), and Park Falls (US-PFa). These sites cover deciduous, evergreen, and mixed forests across different regions of the U.S. (Fig. 1, Table 1). 
Variables used to evaluate the model performance include ET, Net Primary Productivity (NPP), Net Ecosystem Exchange (NEE), and plant biomass. Observed latent heat fluxes were converted to ET using the algorithm suggested by the AmeriFlux data support system (Henderson-Sellers, 1984). Here, NEE is defined as the net carbon exchange between land and the atmosphere. Negative NEE indicates net carbon uptake by forests, while positive values indicate net carbon emissions from forests to the atmosphere. We calculated SWAT simulated NEE as respiration minus NPP. For ET and NEE, observational data were collected from the flux data category of the AmeriFlux dataset, and daily observations of these variables were aggregated to monthly and annual levels for model performance evaluation. Plant biomass data were collected from the AmeriFlux biological dataset (biomass data were not available for the US-MOz and US-WBW sites). We obtained NPP data from the MODIS NPP product (Zhao et al., 2005) for each site. Observational data between 1995 and 1999 were used for parameter calibration, whereas data between 2000 and 2006 were used for model performance evaluation.

\subsection{Carbon cycling representation in SWAT}

Key carbon cycling processes in SWAT include plant growth, carbon allocation, litter fall, litter decomposition, and below-ground carbon cycling (soil organic matter dynamics). In SWAT, NPP is simulated as a function of solar radiation and plant's capability of converting solar energy to plant biomass (Neitsch et al., 2009):

$$
\begin{gathered}
\triangle N P P=\text { Bio_E}_{-} \cdot H \cdot C f r t \cdot r e g \\
r e g=1-\max (f w \cdot f t \cdot f n \cdot f p) \\
f w=1-\frac{E_{t, a c t}}{E_{t}}
\end{gathered}
$$




$$
\begin{aligned}
& \int^{1} \quad \text { when } T_{a v} \leq T_{\text {base }} \\
& f t=\left\{\begin{array}{lr}
1-\exp \left(\frac{-0.1054 \cdot\left(T_{o p t}-T_{a v}\right)^{2}}{\left(T_{a v}-T_{b a s e}\right)^{2}}\right) & \text { when } T_{\text {base }}<T_{a v} \leq T_{o p t} \quad \text { (Equation 4) } \\
1-\exp \left(\frac{-0.1054 \cdot\left(T_{o p t}-T_{a v}\right)^{2}}{\left(2 \cdot T_{o p t}-T_{a v}-T_{b a s e}\right)^{2}}\right) & \text { when } T_{o p t}<T_{a v} \leq 2 \cdot T_{o p t}-T_{\text {base }}
\end{array}\right. \\
& f n=1-\frac{S_{n}}{S_{n}+\exp \left(3.535-0.02597 \cdot S_{n}\right)} \\
& S_{n}=200 \cdot \frac{b i o_{n}}{b i o_{n}, o p t}-0.5 \\
& f p=1-\frac{s_{p}}{s_{p}+\exp \left(3.535-0.02597 \cdot s_{p}\right)} \\
& S_{p}=200 \cdot \frac{b i o_{p}}{b^{2} o_{p}, o p t}-0.5
\end{aligned}
$$

where $\triangle N P P$ is the net carbon assimilation rate on a given day $(\mathrm{kg} \mathrm{C} / \mathrm{ha}) ; B i o \_E$ is the radiationuse efficiency of the plant $\left(\mathrm{kg}\right.$ biomass $\left./ \mathrm{ha} /\left(\mathrm{MJ} / \mathrm{m}^{2}\right)\right) ; H$ is the photosynthetically active radiation on a given day $\left(\mathrm{MJ} / \mathrm{m}^{2}\right)$; reg is the environmental stress regulator on photosynthesis (unitless); $C f r t$ is the specific carbon in biomass $(0.45 \mathrm{~kg} \mathrm{C} / \mathrm{kg}$ biomass); $f w, f n, f p$, and $f t$ are stress factors (unitless) from water, nitrogen, phosphorus, and temperature, respectively; $E_{t, a c t}$ is the actual rate of transpiration $\left(\mathrm{mm} \mathrm{H}_{2} \mathrm{O} /\right.$ day); $E_{t}$ is the potential transpiration $\left(\mathrm{mm} \mathrm{H}_{2} \mathrm{O} /\right.$ day $) ; T_{\text {base }}$ is the minimum temperature for plant to grow $\left({ }^{\circ} \mathrm{C}\right) ; T_{o p t}$ is the optimum temperature for plant to grow $\left({ }^{\circ} \mathrm{C}\right) ; T_{a v}$ is the mean air temperature of a given day $\left({ }^{\circ} \mathrm{C}\right) ; S_{n}$ is the nitrogen stress scaling factor (unitless); bio $_{n}$ is the actual nitrogen mass in plant biomass ( $\left.\mathrm{kg} \mathrm{N} / \mathrm{ha}\right) ;$ bio $_{n, o p t}$ is the optimal nitrogen mass in plant (kg N/ha); $S_{p}$ is the phosphorus stress scaling factor (unitless); bio $p$ is the actual phosphorus mass in plant biomass ( $\mathrm{kg} \mathrm{P} / \mathrm{ha})$; bio p,$o p t_{\text {is }}$ is the optimal phosphorus mass in plant (kg P/ha).

[Table 2] 
Newly assimilated carbon is allocated to aboveground and belowground biomass (root) according to the heat units accumulated for the plant until a given day of the growing season (Neitsch et al., 2009). A fraction of plant biomass is turned over and added to litter pools (Table 2). Values of key parameters regulating carbon cycling in SWAT are listed in Table 2.

The SWAT model's belowground carbon cycling algorithms follow the basic structure of the CENTURY model (Parton et al., 1994), with modifications to accommodate additional processes and functions from the Environmental Policy Integrated Climate (EPIC, Izaurralde et al., 2006) and the Decision Support System for Agrotechnlogy Transfer (DSSAT) models (Gijsman et al., 2002). Details of the soil organic carbon cycling algorithm are provided by Zhang et al. (2013). Here, we further revised the SWAT model's carbon cycling algorithm by allowing surface litter to be transformed to humus and get mixed with the slow carbon pool in the first soil layer. This change was conducted according to Kelly et al. (1997), Parton et al. (2010), and Savage et al. (2013).

\subsection{Model parameterization and improvement}

Since NPP is the primary source of carbon input into forest ecosystems, reasonable simulation of NPP is the prerequisite of satisfying model performance in NEE and plant biomass simulations. In SWAT, carbon uptake through photosynthesis is limited by multiple factors including radiation use efficiency, $\mathrm{N}, \mathrm{P}$, water, and temperature (Equations 1-8). Parameters related to these processes need to be determined to improve SWAT simulations of forest water and carbon fluxes. Based on literature review and field observations, we obtained parameter ranges for different forest types. Next we further calibrated these parameters manually at each site to minimize the difference between simulations and observations. In this study, we focused 
on biophysical parameters of forest ecosystems, and did not adjust other hydrological or biogeochemical parameters.

[Fig. 2]

In SWAT, forest photosynthesis is directly controlled by the radiation use efficiency parameter (BIO_E, Table 2). The default value of this parameter in SWAT for the three forest types is unanimously $15 \mathrm{~kg}$ dry biomass $/ \mathrm{ha} /\left(\mathrm{MJ} / \mathrm{m}^{2}\right)$. However, field observations and other modeling studies indicated that radiation use efficiency could be higher than this default value for deciduous and mixed forests (Hilker et al., 2012), and pine trees have much lower radiation use efficiency than broad leaf species as a result of low photosynthetic capacity (Pangle et al., 2009). Using the US-Ha1 site as an example, we conducted model experiments to test influence of BIO_E on NPP simulation. Fig. 2A shows sensitive response of NPP to changes of this parameter.

Therefore, we calibrated BIO_E based on observational data for the three forest types in SWAT (Table 2). Calibrated parameter values are in the range reported by previous studies. Specifically, calibrated BIO_E (24-27 kg biomass $\left./ \mathrm{ha} /\left(\mathrm{MJ} / \mathrm{m}^{2}\right)\right)$ for mixed forests is close to the upper end of the observed values (10.2-28.8 $\mathrm{kg}$ biomass $\left./ \mathrm{ha} /\left(\mathrm{MJ} / \mathrm{m}^{2}\right)\right)$ derived from across multiple tree species (Schwalm et al., 2006; Zhu et al., 2006). BIO_E for deciduous forests in the new SWAT parameterization varies from 26 to $30 \mathrm{~kg}$ biomass $/ \mathrm{ha} /\left(\mathrm{MJ} / \mathrm{m}^{2}\right)$, which corresponds well with field observations (17.1-35.8 $\mathrm{kg}$ biomass $/ \mathrm{ha} /\left(\mathrm{MJ} / \mathrm{m}^{2}\right)$, Gower et al., 1999) and the suggested parameter range of $20-35 \mathrm{~kg}$ biomass $/ \mathrm{ha} /\left(\mathrm{MJ} / \mathrm{m}^{2}\right)$ by Guo et al. (2015). Calibrated BIO_E (16-18 $\mathrm{kg}$ biomass $\left./ \mathrm{ha} /\left(\mathrm{MJ} / \mathrm{m}^{2}\right)\right)$ for evergreen forests falls well within the range of field 
observations (5-24.2 $\mathrm{kg}$ biomass/ha/ $\left.\left(\mathrm{MJ} / \mathrm{m}^{2}\right)\right)$ of major U.S. temperate evergreen tree species (Gower et al., 1999).

Temperature is another important factor controlling forest carbon assimilation. The default value of the optimum temperature (T_OPT) for all three forest types is set to $30^{\circ} \mathrm{C}$. However, in other ecosystem models, such as the Century model (Parton et al., 1994), this parameter is set to $20-25^{\circ} \mathrm{C}$ for most plant species. Furthermore, field observations suggested that temperate forests reach optimal photosynthesis at around $25^{\circ} \mathrm{C}$ (Hikosaka et al., 2007). As a result, we decreased the optimum temperature to better stimulate plant growth (Table 2). Flux towers observe ecosystem respiration in winter. However, the default SWAT parameterization assumes that soil respiration drops to zero when air temperature is below the freezing point. Here, we allow soil litter and soil organic carbon decomposition to occur when air temperature is above $-5^{\circ} \mathrm{C}$ to improve simulations of litter and organic matter decomposition in cold seasons according to Mikan et al. (2002). Base temperature (T_Base) for plant growth varies over different plant species and site conditions, and thus needs to be calibrated to better simulate plant phenology and associated carbon and water fluxes (Farr and Harris, 1979).

In addition, maximum leaf area index (BLAI) is set to 5 for all forest types in the default parameterization, which oversimplifies the structural difference among different forest types. We tuned this parameter according to the AmeriFlux biological data to better simulate forest foliage development and associated water and carbon fluxes. In SWAT, accumulation of plant biomass is regulated by both carbon input through photosynthesis and carbon output through litter fall. Therefore, parameters regulating litter fall may affect biomass estimates. The default value (0.3) of leaf to biomass fraction (BIO_LEAF) is significantly higher than AmeriFlux observations 
(0.005-0.064). We further calibrated this parameter based on AmeriFlux biological data to better estimate litter falls in SWAT (Table 2).

Nutrient supply is another important factor influencing forest carbon uptake. Soil P supply has significant controls regulating photosynthesis (Menge et al., 2012). In natural ecosystems, weathering of parent minerals is the primary pathway of new $\mathrm{P}$ inputs to ecosystems. However, this process in not accounted for in SWAT. Therefore, we added P input through weathering into SWAT to account for this missing nutrient flux in the model. At the Harvard Forest site, we simulated a leaching rate of $1.26 \mathrm{~kg} \mathrm{P} / \mathrm{ha} / \mathrm{year}$, which reduced soil inorganic P content by $47.5 \%$ over a long period (Fig. S1). Sensitivity tests show that P limits forest growth through the entire simulation period, and insufficient P supply may reduce NPP by more than $50 \%$ (Fig. 2B). The parent material weathering simulation algorithm is adopted from the Century4.5 model (Parton et al., 1994):

$$
\begin{gathered}
R_{w}=\text { Ppar } \times \text { wteff } \times \text { teff } \\
\text { wteff }=\text { fwater } \times \text { ftem } \\
\text { fwater }=1 \quad \text { if rwater }>13 \\
\text { fwater }=\frac{1}{1+10 \times e^{-6 \times r w a t e r}} \quad \text { if rwater }>13 \\
\text { rwater }=\frac{\Theta-\Theta_{\text {wilt }}}{\Theta_{f c}-\Theta_{\text {wilt }}} \\
\text { normalizer }=11.75+(29.7 / 3.14) \times \text { atan }(3.14 \times 0.031 \times(30-15.4) \\
\text { teff }=12 \times \frac{\text { tef } 1+(\text { tef } 2 / 3.14) \times \text { atan }(3.14 \times \text { tef } 3 \times(p f i n e-0.7))}{365} \\
p \text { fine }=\text { clay }+ \text { silt }(3.14 \times 0.031 \times(T-15.4)
\end{gathered}
$$


where $R_{w}$ is the weathering rate of parent phosphorus ( $\left.\mathrm{g} \mathrm{P} / \mathrm{m}^{2} / \mathrm{day}\right) ; P_{p a r}$ is the parent $\mathrm{P}$ in soil column (21.5-84.3g P/m²), which is obtained from soil phosphorus synthesis data (Yang and Post, 2011); wteff represent impacts of temperature and soil water content on weathering, and teff is the soil texture factor on weathering; $T$ is soil temperature $\left({ }^{\circ} \mathrm{C}\right) ; \boldsymbol{\theta}$ is soil water content of the top $15 \mathrm{~cm}$ soil layer (\%); $\boldsymbol{\theta}_{w i l t}$ is soil water content at the wilting point (\%); $\boldsymbol{\theta}_{f c}$ is the soil field capacity (\%); tefl, tef2, and tef 3 are dimensionless parameters that denote soil texture impacts on weathering; pfine is the faction of fine particles in soil; clay is the fraction of clay in soil; silt is the fraction of silt in soil.

\subsection{Model setup and performance evaluation}

For the site scale SWAT simulation, each site was treated as a hydrologic response unit (HRU). The latitude/longitude and elevation of selected sites was collected directly from the AmeriFlux website (ameriflux.lbl.gov). Climate data (precipitation, temperature, solar radiation, wind, and humidity) were obtained from the North American Land Data Assimilation System (NLDAS) dataset (Cosgrove et al., 2003). We used the Soil Survey Geographic Database (SSURGO) downloaded from the Geospatial Data Gateway (https://gdg.sc.egov.usda.gov/) to obtain soil properties including soil layer depth, soil texture, soil bulk density, soil organic carbon content, and soil erosion coefficient at each site. Model simulations were conducted from 1980 to 2009. Model performance evaluation was mainly focused on the 2000s, depending on availability and quality of water and carbon flux observations from the sites.

We evaluated model performance at multiple temporal and spatial scales. We first examined model simulations of multiple-year average annual ET, NPP, NEE, and biomass at each site to identify the systematic discrepancies between model estimates and observations. 
With improved parameterization and representation of phosphorus input, we further checked model simulations of monthly ET and NEE to examine the model's capability in capturing seasonal variability of these two variables at each site. Finally, model performance in simulating NEE across all sites was tested by comparing annual NEE estimates at the ten sites against observations. Coefficient of determination $\left(\mathrm{r}^{2}\right)$ and root mean squared error (RMSE) (Legates and McCabe, 1999) were employed to quantify the differences between model predictions and field observations.

\section{Results}

\subsection{SWAT simulations with the default parameterization}

[Fig. 3]

In the simulations with the default parameterization, SWAT generally simulated well annual ET at the ten AmeriFlux sites (Fig. 3A). SWAT also captured well the interannual and seasonal variability of ET at each site, with significant correlations found for all sites at the monthly scale $(P<0.01$, Fig.S2 in the supplement). SWAT simulated annual ET was higher than the observations by $10-30 \%$ at most sites. The best modeled ET occurred at the US-UMB site, where ET was overestimated by $13 \%$, while the largest discrepancy occurred at the US-Ho1 site, where ET was overestimated by approximately $90 \%$.

The default SWAT substantially underestimated forest NPP across all sites (Fig. 3B). NPP estimates derived from the MODIS products range from 101 to $887 \mathrm{~g} \mathrm{C} / \mathrm{m}^{2} / \mathrm{year}$, with the highest NPP of $887 \mathrm{~g} \mathrm{C} / \mathrm{m}^{2} /$ year found at the US-Ha1site, and the lowest NPP of $101 \mathrm{~g}$ $\mathrm{C} / \mathrm{m}^{2} /$ year at US-MOz. SWAT simulated NPP demonstrated less spatial variability than the satellite data, with a much narrower range of 87-295 $\mathrm{g} \mathrm{C} / \mathrm{m}^{2} /$ year. 
Flux tower observations suggest that most of the selected sites are net carbon sinks, except for the US-PFa site (Fig. 3C). The ability of carbon sequestration varied substantially across the ten sites. The US-WBW site exhibited higher carbon uptake rates $\left(-916 \mathrm{~g} \mathrm{C} / \mathrm{m}^{2} / \mathrm{year}\right)$ than other sites (> -460 g C/m²/year). Land-atmosphere carbon exchanges at US-Syv and USNR1 were close to an equilibrium state, with low NEE of $-22.8 \mathrm{~g} \mathrm{C} / \mathrm{m}^{2} /$ year and $-24.9 \mathrm{~g}$ $\mathrm{C} / \mathrm{m}^{2} /$ year, respectively. The US-PFa site acted as net a carbon source and emitted $47.9 \mathrm{~g}$ $\mathrm{C} / \mathrm{m}^{2} /$ year on average. The signs of the default SWAT simulated NEE agreed with the observations at five of the ten sites. For US-Syv, US-UMB, US-MOz, US-WBW, and US-NR1, SWAT estimated NEE was opposite to observed NEE in direction. Furthermore, the default simulation reasonably reconstructed seasonal variability of NEE at the monthly scale, although there were significant discrepancies in the NEE magnitude (see Fig. S3 in the supplementary material).

Overall, the SWAT simulations with the default parameterization and processes failed to provide reasonable estimates of carbon storage in plant biomass at the selected sites (Fig. 3D). Forests store a huge amount of carbon in the living biomass, with average carbon densities ranging from 7490 to $13280 \mathrm{~g} \mathrm{C} / \mathrm{m}^{2}$ over the ten sites. Lowest biomass occurred at the US-WCr site, while highest biomass was found at the deciduous US-MMS site. The default SWAT model simulations of plant biomass ranged from 278 to $1028 \mathrm{~g} \mathrm{C} / \mathrm{m}^{2}$, which are much lower than observations.

\subsection{Model performance with the new parameterization and improved representation of phosphorus input}

[Fig. 4] 
[Fig. 5]

With the new parameterization and P cycling representation, the performance of SWAT in estimating ET was further refined (Fig. 4A). The overestimation of ET was pronouncedly reduced over all selected sites. As well, we obtained better simulation results explaining the temporal patterns of ET (Fig. 5). For example, $\mathrm{r}^{2}$ for monthly ET simulations is larger than 0.77 for all sites, with the best ET simulation achieved at the US-PFa site $\left(r^{2}=0.923\right.$, RMSE $\left.=9.95\right)$.

Annual NPP simulated with the improved SWAT matched much closer to the observations (Fig. 4B) than the default SWAT simulations. Newly estimated NPP increased by more than $208 \%$ on average compared with the default simulations, or by $240-740 \mathrm{~g} \mathrm{C} / \mathrm{m}^{2} /$ year over the ten sites. New NPP simulations matched well observations at most sites, except for USWCr and US-MOz, where SWAT overestimated NPP by approximately $137 \%$ and $650 \%$, respectively. For the other sites, differences between simulated and observed NPP were less than $250 \mathrm{~g} \mathrm{C} / \mathrm{m}^{2} /$ year.

[Fig. 6]

The SWAT NEE estimates have also been greatly improved in the new simulations (Fig. 4C). Comparison of simulated monthly NEE with observations indicated that both seasonality and magnitude of NEE were well simulated (Fig. 6). In the new simulations, the number of sites with correctly simulated signs of NEE increased from 5 to 9 , with the only exception at US-Syv. Note that US-Syv had a low NEE of $-22.8 \mathrm{~g} \mathrm{C} / \mathrm{m}^{2} / \mathrm{year}$, and SWAT simulated NEE at this site was also close to neutral (Fig. 4). For the monthly comparison, $\mathrm{r}^{2}$ ranged from 0.53 to 0.91 across the ten sites, with the best model performance achieved at the US-Ha1 site.

Not surprisingly, the newly simulated plant biomass matched much better against observations (Fig. 4D) than the default simulations. Plant biomass increased to $7807-12354 \mathrm{~g}$ 
$\mathrm{C} / \mathrm{m}^{2}$ from the average of $624 \mathrm{~g} \mathrm{C} / \mathrm{m}^{2}$ in the default simulations. Differences between improved model simulations and observations were less than $30 \%$ across the selected sites.

[Fig. 7]

The significant correlation between simulated annual NEE and field observations across all the ten sites further demonstrates the improved model skills in modeling forest carbon cycling (Fig. 7). The new SWAT model explained up to $78.4 \%$ of the spatial variability in multi-year average NEE at the ten sites that represent a broad range of environment conditions (climate, soil, altitude, etc.) and multiple forest types. This indicates the robustness of SWAT in simulating forest carbon cycling, as well as the feasibility of employing the model to investigate how changing climatic and anthropogenic drivers may affect ecosystem structure and functioning.

\section{Discussion}

\subsection{SWAT ET estimates in forest ecosystems}

As an important process of terrestrial water cycling, ET has been widely investigated. Water loss through ET not only influences soil water contents but also affects heat fluxes between land surface and the atmosphere. It was estimated that ca. $60 \%$ of the precipitation falling on the land surface is returned to the atmosphere through ET at the global scale (Oki and Kanae, 2006). In addition, ET returns up to $30 \%$ of the radiation energy received by land to the air (Trenberth et al., 2009). Reasonable estimation of ET is critical for robust understanding of a series of interconnected ecological and hydrological processes. The default SWAT simulations reconstructed well the seasonal patterns of ET over most sites, indicating the reliable capability of SWAT in modeling forest hydrology. Our improvements in LAI and plant growth parameters further improved ET simulations by SWAT and reduced the overestimation of ET. These results 
consistently demonstrate the strength of SWAT in addressing coupled water cycling and plant growth processes in forest ecosystems.

\subsection{Improvement of SWAT simulations of forest carbon cycling}

SWAT has been widely tested for agricultural ecosystems (Zhang et al. 2013, 2015), with few studies examining its performance in modeling forest ecosystems. Default values of key parameters regulating carbon cycling and model representation of P supply in SWAT need to be improved to reliably depict biophysical and biogeochemical processes in unmanaged ecosystems, such as forests.

Insufficient representation of the growth of perennial plants is one reason for the unsatisfactory model performance in simulating forest ecosystems with the default parameterization. Many of the SWAT parameters were developed and calibrated based on observations from annual crops. However, the differences in size, lifespan, and carbon cycling processes between trees and crops (Zan et al., 2001) have challenged the default parameterization of plant physiological process for applications of SWAT to forests. For example, sensitive parameters (BIO_E and BIO_LEAF) in the default SWAT are not well configured for forests. BIO_E in the original SWAT does not differentiate between deciduous and evergreen forests, and is lower than literature reported values (Hilker et al., 2012). For BIO_LEAF, the default value (0.3) was much higher than field observations at the AmeriFlux sites (0.015-0.06) and reported values (0.03) from a synthesis study of 70 temperate forest observations by Poorter et al., (2012).

Insufficient representation of nutrient cycling is another reason responsible for the underestimated carbon assimilation and biomass accumulation in the default simulations. Unlike 
croplands that receive large amounts of chemical fertilizer to balance the nutrient effluxes through harvesting and leaching (Howarth et al., 2002), forests have much tighter nutrient budgets. Phosphorus needed to support tree growth is mainly provided by natural recycling and internal redistribution (Attiwill and Adams, 1993). Although new nutrient inputs through parent material weathering only account for a small proportion of the total $\mathrm{P}$ storage in forests, this input is critical for forest ecosystems to balance the outputs through leaching to rivers and to maintain nutrient sustainability (Cole, 1995). Missing this input in default SWAT limits nutrient supply for plant growth and leads to the low NPP and biomass. This finding highlights the importance of constraining uncertainties in nutrient cycling in order to better simulate forest carbon fluxes.

This is the first work that has diagnosed the parameterization and process representation of forested ecosystems in the SWAT model. The tests of the new schemes of modeling forests in SWAT span a wide range of climate and physiographic conditions, as well as include three major forest types in the U.S. The overall satisfying agreement between model simulations and observations with the improved parameterization demonstrates SWAT's capability in reconstructing land-atmosphere carbon exchanges. For example, the average correlation coefficient ( $r$, or the square root of coefficient of determination) of monthly NEE simulations over the ten forest sites is 0.85 , which is comparable with the performance $(0<r<0.95)$ of a group of widely-used forest ecosystem models examined in Schwalm et al. (2010). Carbon cycling is closely coupled with water and nutrients in ecosystems (Xia et al., 2015). The improved performance of SWAT in simulating forests, along with its existing strength in representing agricultural ecosystems, makes SWAT a powerful tool to understanding terrestrial 
carbon dynamics, in addition to water and nutrient cycling (Shen et al., 2013), at the watershed scale.

\subsection{Future directions for model improvement}

The above improvements in parametrization and $\mathrm{P}$ cycling representation are based on the existing forest module within SWAT. We also identify several aspects to further enhance the structure of SWAT as well as to better simulate terrestrial carbon cycling. These directions include refining the classification of forest types, detailing the definition of biomass carbon pools, and revising litter fall processes.

Currently, the SWAT model characterizes three key forest types (deciduous, mixed, and evergreen forests) based on their phenological features. Field investigations suggest that aggregating different forest species into one phenology group may oversimplify processes relevant to carbon cycling (Sierra et al., 2009). Specifically, structural characteristics (such as broad and needle leaves) of different tree species within the same phenological group (e.g. evergreen forest) are important in affecting water and carbon exchanges between vegetation's canopy and the atmosphere (Abrams and Kubiske, 1990). Moreover, this current parameterization is reasonable for temperate forest, but may not be applicable to tree species with distinct features in other climate regions, such as tropical and boreal areas. A more explicit categorization of forest types based on the plant functional types, as adopted in many ecosystem models (Oleson et al., 2013), needs to be developed to allow SWAT users having more flexibility in applying the model to broad-spatial-scale investigations. We also note that further adoption of mechanisms describing plant competition for light, water, and nutrient following mechanisms such as the ALMANAC model may further improve simulation of carbon partitioning among different tree species (Johnson et al., 2009). 
The current version of SWAT only uses three plant biomass carbon pools (i.e. leaf, root, and a pool including all the remaining plant biomass) to represent carbon storage in forests, and does not explicitly consider the structural differences of tissues (such as leaf, branches, large wood, fine root, and coarse root) in woody plants (Oleson et al., 2013; Parton et al., 1994). This simplified representation of vegetation carbon stocks in SWAT misses explicit representation of carbon allocation and storage in different plant tissues, therefore introduced uncertainties in the simulations of litter production and subsequent decomposition (Potter and Klooster, 1997). Differences in bioactivity result in faster turnover of active plant tissues (such as leaf and fine root) than recalcitrant tissues (such as large wood and coarse root) (Xia et al., 2012). These processes are not represented by the current version of SWAT mainly due to the simplification of plant biomass carbon pools. Although the current version of SWAT with the improved parameters provides reasonable estimates of the major carbon fluxes and storage in tree biomass, incorporation of a more explicit description of different biomass carbon pools and associated processes into SWAT is expected to further reduce uncertainties in forest simulations.

The timing of litter fall in SWAT deserves further improvement. Litter fall occurs when day length reaches the dormancy threshold in the model. When dormancy starts, a fraction of aboveground biomass falls onto the ground as litter on that day. This process is inconsistent with the fact that leaf fall may last for a couple of weeks (Niinemets and Tamm, 2005). The inadequacy of SWAT in simulating the litter fall process is likely to be a cause for the mismatch between modeled and observed NEE in cold seasons (Fig. 6). In addition, integrating this work with previous efforts related to plant growth modifications (e.g. the new leaf area index evolution algorithm by Strauch et al. (2013)) holds the promise to further enhance SWAT for watershed scale representation of water and carbon cycling processes in forest ecosystems. 


\section{Conclusion}

SWAT is a watershed scale model which has been widely used to investigate effects of natural and anthropogenic disturbances on water and nutrient cycling. However, the model performance in forest ecosystems has not been extensively tested. Considering the important role of forests in regional carbon, water, and nutrient cycling and the complex interactions of these elements at the watershed scale, it is critical to evaluate SWAT's capability in simulating forest water and carbon fluxes.

Here we examined SWAT simulations over ten forest sites in the U.S. The default parameterization in SWAT resulted in reasonable ET simulations, but led to large errors in NPP, NEE, and plant biomass estimates as compared with observations. By deriving new parameter values from literature review, field observations, and site-specific calibration, and adding phosphorus supply from parental material weathering, the model performance in simulating NPP, NEE, and plant biomass was significantly improved. SWAT's performance for simulating monthly NEE is comparable to a group of forest ecosystem models examined in a model intercomparison effort that also used AmeriFlux carbon flux data in the U.S. The Improvement of the unrealistic default parameter values helps build the foundation for future application of SWAT for simulating forest ecosystems.

This effort is the first study examining SWAT for simulating carbon fluxes in forest ecosystems against flux tower observations. Our analyses provide complimentary information to the existing knowledge about SWAT's strengths and weaknesses in modeling ecosystem dynamics. The new parameterization and phosphorus cycling representation developed in this study lay the foundation toward integrated investigations of the coupled carbon, nutrient, and water cycling using SWAT. We also discussed several future research directions that hold the 
potential to further improve the structure of SWAT to mechanistically represent carbon cycling in forest ecosystems. 


\section{Acknowledgements:}

We sincerely appreciate the valuable comments provided by the anonymous reviewers. This work was funded by the NASA New Investigator Award (NIP, NNH13ZDA001N) and Terrestrial Ecology Program (NNH12AU03I) as part of the North American Carbon Program, and the DOE Great Lakes Bioenergy Research Center (DOE BER Office of Science DE-FC0207ER64494, DOE BER Office of Science KP1601050, DOE EERE OBP 20469-19145). 


\section{References:}

Abrams, M.D., Kubiske, M.E., 1990. Leaf structural characteristics of 31 hardwood and conifer tree species in central Wisconsin: influence of light regime and shade-tolerance rank. Forest $31,245-253$.

Aragão, L.E.O.C., 2012. The rainforest's water pump. Nature 8-9. doi:10.1038/nature11485

Arnold, J.G., Srinivasan, R., Muttiah, R.S., Willianms, J.R., 1998. Large area dyrologic modeling and assessment part 1:model development. J. Am. Water Resour. Assoc. 34, 73 89.

Arnold, J., Chinnasamy, S., Di Luzio, M., Haney, E. B., Kannan, N., White, M., 2010. The HUMUS/SWAT National Water Quality Modeling System. Available at http:// www.nrcs.usda.gov/Internet/FSE_DOCUMENTS/stelprdb1042103.pdf, verified on February 3, 2016.

Attiwill, P.M., Adams, M.A, 1993. Nutrient cycling in forests. New Phytol. 124, 561-582.

Aust, W.M., Blinn, C.R., 2004. Forestry Best Management Proactices for Timber Harvesting and Site Preparation in the Eastern United States: An overview of Water Quality and Productivity Research During the Past 20 Years(1982-2002). Water, Air, Soil Pollution Focus 4, 5-36.

Baffaut, C., John Sadler, E., Ghidey, F., Anderson, S.H., 2015. Long-Term Agroecosystem Research in the Central Mississippi River Basin: SWAT Simulation of Flow and Water Quality in the Goodwater Creek Experimental Watershed. J. Environ. Qual. 44, 84. doi:10.2134/jeq2014.02.0068

Bosch, J.M., Hewlett, J.D., 1982. A review of Catchment Expreriments to Determine the Effect of Vegetation Changes on Water Yield and Evapotranspiration. J. Hydrol. 55, 3-23.

Briggs, R., Hornbeck, J., Smith, C., Lemin, R., McCormack, M., 2000. Long-term effects of forest management on nutrient cycling in spruce-fir forests. For. Ecol. Manage. 138, 285299. doi:10.1016/S0378-1127(00)00420-5

Brown, S., Versace, V., Lester, R., Walter, M., 2015. Assessing the impact of drought and forestry on streamflows in south-eastern Australia using a physically based hydrological model. Environ. Earth Sci. 74, 6047-6063. doi:10.1007/s12665-015-4628-8

Canton, M., Anschutz, P., Coynel, A., Polsenaere, P., Auby, I., Poirier, D., 2010. Nutrient export to an Eastern Atlantic coastal zone: first modeling and nitrogen mass balance.

Biogeochemistry 107, 361-377. doi:10.1007/s10533-010-9558-7

Cole, D.W., 1995. Soil nutrient supply in natural and managed forests. Plant Soil 168, 43-53. doi:10.1007/BF00029312

Cook, B.D., Davis, K.J., Wang, W., Desai, A., Berger, B.W., Teclaw, R.M., Martin, J.G., Bolstad, P. V., Bakwin, P.S., Yi, C., Heilman, W., 2004. Carbon exchange and venting anomalies in an upland deciduous forest in northern Wisconsin, USA. Agric. For. Meteorol. 126, 271-295. doi:10.1016/j.agrformet.2004.06.008

Cosgrove, B.A., Lohmann, D., Mitchell, K.E., Houser, P.R., Wood, E.F., Schaake, J.C., Robock, 
A., Marshall, C., Sheffield, J., Duan, Q., Luo, L., Higgins, R.W., Pinker, R.T., Tarpley, J.D., Meng, J., 2003. Real-time and retrospective forcing in the North American Land Data Assimilation System (NLDAS) project. J. Geophys. Res. 108, 8842. doi:10.1029/2002JD003118

Davis, K.J., Bakwin, P.S., Yi, C., Berger, Bradford, D., Zhao, C., Teclaw, R.D., Isebrands, J.G., 2003. The annual cycles of $\mathrm{CO} 2$ and $\mathrm{H} 2 \mathrm{O}$ exchanges over a northern mixed forest as observed from a very tall tower. Glob. Chang. Biol. 9, 1278-1293. doi:10.1029/2009JD012832

Delire, C., Foley, J.A., 1999. Evaluating the Performance of a Land Surface/Ecosystem Model with Biophysical Measurements from Contrasting Environments. J. Geogr. Res. 104, 16895-16909.

Desai, A.R., Bolstad, P.V., Cook, B.D., Davis, K.J., Carey, E.V., 2005. Comparing net ecosystem exchange of carbon dioxide between an old-growth and mature forest in the upper Midwest, USA. Agric. For. Meteorol. 128, 33-55. doi:10.1016/j.agrformet.2004.09.005

El-Khoury, A., Seidou, O., Lapen, D.R., Que, Z., Mohammadian, M., Sunohara, M., Bahram, D., 2015. Combined impacts of future climate and land use changes on discharge, nitrogen and phosphorus loads for a Canadian river basin. J. Environ. Manage. 151, 76-86. doi:10.1016/j.jenvman.2014.12.012

Entekhabi, D., Eagleson, P.S., 1989. Land Surface Hydrology Parameterization for Atmospheric General Circulation Models Including Subgrid Scale Spatial Variability. J. Clim. 2, 816831.

Faramarzi, M., Srinivasan, R., Iravani, M., Bladon, K. D., Abbaspour, K. C., Zehnder, A. J., Goss, G. G., 2015. Setting up a hydrological model of Alberta: Data discrimination analyses prior to calibration. Environ. Model. Softw. 74, 48-65.

Farr, W. A, Harris, A., 1979. Site index of sitka spruce along the pacific coast related to latitude and temperatures. For. Sci. 25, 145-153.

Gijsman, A. J., Hoogenboom, G., Parton, W.J., Kerridge, P.C., 2002. Modifying DSSAT for low-input agricultural systems, using a SOM module from CENTURY. Agron. J. 94, 462474.

Gough, C.M., Hardiman, B.S., Nave, L.E., Bohrer, G., Maurer, K.D., Vogel, C.S., Nadelhoffer, K.J., Curtis, P.S., 2013. Sustained carbon uptake and storage following moderate disturbance in a Great Lakes forest. Ecol. Appl. 23, 1202-1215. doi:10.1890/12-1554.1

Gower, S.T., Kucharik, C.J., Norman, J.M., 1999. Direct and Indirect Estimation of Leaf Area Index , f APAR , and Net Primary Production of Terrestrial Ecosystems. Remote Sens. Environ. 70, 29-51.

Gu, L., Massman, W.J., Leuning, R., Pallardy, S.G., Meyers, T., Hanson, P.J., Riggs, J.S., Hosman, K.P., Yang, B., 2012. The fundamental equation of eddy covariance and its application in flux measurements. Agric. For. Meteorol. 152, 135-148.

doi:10.1016/j.agrformet.2011.09.014 
Gu, L., Meyers, T., Pallardy, S.G., Hanson, P.J., Yang, B., Heuer, M., Hosman, K.P., Riggs, J.S., Sluss, D., Wullschleger, S.D., 2006. Direct and indirect effects of atmospheric conditions and soil moisture on surface energy partitioning revealed by a prolonged drought at a temperate forest site. J. Geophys. Res. 111, 1-13. doi:10.1029/2006JD007161

Gu, L., Pallardy, S.G., Hosman, K.P., Sun, Y., 2015. Drought-influenced mortality of tree species with different predawn leaf water dynamics in a decade-long study of a central US forest. Biogeosciences 12, 2831-2845. doi:10.5194/bg-12-2831-2015

Hart, P.B.S., Clinton, P.W., Allen, R.B., Nordmeyer, A. H., Evans, G., 2003. Biomass and macro-nutrients (above- and below-ground) in a New Zealand beech (Nothofagus) forest ecosystem: Implications for carbon storage and sustainable forest management. For. Ecol. Manage. 174, 281-294. doi:10.1016/S0378-1127(02)00039-7

Henderson-Sellers, B., 1984. A new formula for latent heat of vaporization of water as a function of temperature. Q. J. R. Meteorol. Soc. 110, 1186-1190.

Hikosaka K., Nabeshima E., Hiura T., 2007. Seasonal changes in the temperature response of photosynthesis in canopy leaves of Quercus crispula in a cool-temperate forest. Tree physiology.27, 1035-1041.

Hilker, T., Hall, F.G., Tucker, C.J., Coops, N.C., Black, T.A., Nichol, C.J., Sellers, P.J., Barr, A., Hollinger, D.Y., Munger, J.W., 2012. Data assimilation of photosynthetic light-use efficiency using multi-angular satellite data: II Model implementation and validation. Remote Sens. Environ. 121, 287-300. doi:10.1016/j.rse.2012.02.008

Holvoet, K., van Griensven, A., Gevaert, V., Seuntjens, P., Vanrolleghem, P.A., 2008. Modifications to the SWAT code for modelling direct pesticide losses. Environ. Model. Softw. 23, 72-81. doi:10.1016/j.envsoft.2007.05.002

Howarth, R.W., Boyer, E.W., Pabich, W.J., Galloway, J.N., 2002. Nitrogen use in the United States from 1961-2000 and potential future trends. Ambio 31, 88-96.

Izaurralde, R.C., Williams, J.R., McGill, W.B., Rosenberg, N.J., Jakas, M.C.Q., 2006. Simulating soil $\mathrm{C}$ dynamics with EPIC: Model description and testing against long-term data. Ecol. Modell. 192, 362-384. doi:10.1016/j.ecolmodel.2005.07.010

Jin, S., Yang, L., Danielson, P., Homer, C., Fry, J., Xian, G., 2013. A comprehensive change detection method for updating the National Land Cover Database to circa 2011. Remote Sens. Environ. 132, 159-175. doi:10.1016/j.rse.2013.01.012

Johnson M.V.V., MacDonald J., Kiniry, J. R., Arnold, J. 2009. ALMANAC: A potential tool for simulating agroforestry yields and improving SWAT simulations of agroforestry watersheds. International Agricultural Engineering Journal. 18. 51-58.

Kelly, R.H., Parton, W.J., Crocker, G.J., Grace, P.R., Klir, J., Korschens, M., Poulton, P.R., Richter, D.D., 1997. Simulating trends in soil organic carbon in long-term experiments using the Ccentury model. Geoderma 81, 75-90. doi:10.1016/S0016-7061(97)00082-7

Legates, D. R., McCabe, G. J., 1999. Evaluating the use of "goodness of fit" measures in hydrologic and hydroclimatic model validation. Water Resour. Res. 35, 233-241. 
Leta, O.T., Nossent, J., Velez, C., Shrestha, N.K., van Griensven, A., Bauwens, W., 2015. Assessment of the different sources of uncertainty in a SWAT model of the River Senne (Belgium). Environ. Model. Softw. 68, 129-146. doi:10.1016/j.envsoft.2015.02.010

Menge, D.N.L., Hedin, L.O., Pacala, S.W., 2012. Nitrogen and phosphorus limitation over longterm ecosystem development in terrestrial ecosystems. PLoS One 7, e42045. doi:10.1371/journal.pone.0042045

Mikan, C.J., Schimel, J.P., Doyle, A.P., 2002. Temperature controls of microbial respiration in arctic tundra soils above and below freezing. Soil Biol. Biochem. 34, 1785-1795. doi:10.1016/S0038-0717(02)00168-2

Monson, R., Turnipseed, A. A., 2002. Carbon sequestration in a high elevation, subalpine forest. Glob. Chang. Biol. 459-478.

Mulholland, P.J., Hill, W.R., 1997. Seasonal patterns in streamwater nutrient and dissolved organic carbon concentrations: Separating catchment flow path and in-stream effects. Water Resour. Res. 33, 1297. doi:10.1029/97WR00490

Niinemets, U., Tamm, U., 2005. Species differences in timing of leaf fall and foliage chemistry modify nutrient resorption efficiency in deciduous temperate forest stands. Tree Physiol. 25, 1001-1014. doi:10.1093/treephys/25.8.1001

Neitsch, S.L., Arnold, J.G., Kiniry, J. 1R., Willianms, J.R., 2009. Soil \& Water Assessment Tool Theoretical Documentation Version 2009. Texas A\&M University System, College Station, Texas.

Oleson, K.W., Lawrence, D.M., Bonan, G.B., Drewniak, B., Huang, M., Charles, D., Levis, S., Li, F., Riley, W.J., Zachary, M., Swenson, S.C., Thornton, P.E., 2013. Technical Description of Version 4.5 of the Community Land Model (CLM). Internatiional center for Atmospheric Research, Boulder, Colorado.

Oki, T., Kanae. S., 2006. Global hydrological cycles and world water resources. Science. $313,1068-72$

Pangle, L., Vose, J.M., Teskey, R.O., 2009. Radiation use efficiency in adjacent hardwood and pine forests in the southern Appalachians. For. Ecol. Manage. 257, 1034-1042. doi:10.1016/j.foreco.2008.11.004

Parton, W.J., Ojima, D.S., Cole, C.V., Schimel, D.S., 1994. A general model for soil organic matter dynamics: Sensitivity to litter chemistry, texture and management. In: Quantitative Modeling of Soil Forming Processes, SSSA Spec. Public No. 39. MAdison, WI.

Parton, W.J., Hanson, P.J., Swanston, C., Torn, M., Trumbore, S.E., Riley, W., Kelly, R., 2010. ForCent model development and testing using the Enriched Background Isotope Study experiment. J. Geophys. Res. Biogeosciences 115, 1-15. doi:10.1029/2009JG001193

Poorter H., Niklas K. J., Reich P. B., Oleksyn J., Poot P. Mommer L., 2012. Biomass allocation to leaves, stems and roots: Meta-analyses of interspecific variation and environmental control. New Phytologist. 1993. 30-50.

Potter, C.S., Klooster, S., 1997. Global model estimates of carbon and nitrogen storage in litter and soil pools: response to changes in vegetation quality and biomass allocation. Tellus B 
$49,1-17$.

Richardson, A.D., Hollinger, D.Y., Dail, D.B., Lee, J.T., Munger, J.W., O’Keefe, J., 2009. Influence of spring phenology on seasonal and annual carbon balance in two contrasting New England forests. Tree Physiol. 29, 321-331. doi:10.1093/treephys/tpn040

Savage, K.E., Parton, W.J., Davidson, E.A., Trumbore, S.E., Frey, S.D., 2013. Long-term changes in forest carbon under temperature and nitrogen amendments in a temperate northern hardwood forest. Glob. Chang. Biol. 19, 2389-2400. doi:10.1111/gcb.12224

Schmid, H.P., Grimmond, C.S.B., Cropley, F., Offerle, B., Su, H.B., 2000. Measurements of $\mathrm{CO} 2$ and energy fluxes over a mixed hardwood forest in the mid-western United States. Agric. For. Meteorol. 103, 357-374. doi:10.1016/S0168-1923(00)00140-4

Schwalm, C.R., Williams, C.A., Schaefer, K., Anderson, R., Arain, M.A., Baker, I., Barr, A., Black, T.A., Chen, G., Chen, J.M., Ciais, P., Davis, K.J., Desai, A., Dietze, M., Dragoni, D., Fischer, M.L., Flanagan, L.B., Grant, R., Gu, L., Hollinger, D., Izaurralde, R.C., Kucharik, C., Lafleur, P., Law, B.E., Li, L., Li, Z., Liu, S., Lokupitiya, E., Luo, Y., Ma, S., Margolis, H., Matamala, R., McCaughey, H., Monson, R.K., Oechel, W.C., Peng, C., Poulter, B., Price, D.T., Riciutto, D.M., Riley, W., Sahoo, A.K., Sprintsin, M., Sun, J., Tian, H., Tonitto, C., Verbeeck, H., Verma, S.B., 2010. A model-data intercomparison of $\mathrm{CO}_{2}$ exchange across North America: Results from the North American Carbon Program site synthesis. J. Geophys. Res. 115, G00H05. doi:10.1029/2009JG001229

Shen, Z., Chen, L., Hong, Q., Qiu, J., Xie, H., Liu, R., 2013. Assessment of nitrogen and phosphorus loads and causal factors from different land use and soil types in the Three Gorges Reservoir Area. Sci. Total Environ. 454-455, 383-392.

doi:10.1016/j.scitotenv.2013.03.036

Sierra, C. A., Loescher, H.W., Harmon, M.E., Richardson, A.D., Hollinger, D.Y., Perakis, S.S., 2009. Interannual variation of carbon fluxes from three contrasting evergreen forests: the role of forest dynamics and climate. Ecology 90, 2711-2723. doi:10.1890/08-0073.1

Strauch, M., Volk, M., 2013. SWAT plant growth modification for improved modeling of perennial vegetation in the tropics. Ecological Modelling, 269, 98-112.

Trenberth, K.E., Fasullo, J.T., Kiehl, J., 2009. Earth's global energy budget. Bull. Am. Meteorol. Soc. 90, 311-323.

Urbanski, S., Barford, C., Wofsy, S., Kucharik, C., Pyle, E., Budney, J., McKain, K., Fitzjarrald, D., Czikowsky, M., Munger, J.W., 2007. Factors controlling CO2 exchange on timescales from hourly to decadal at Harvard Forest. J. Geophys. Res. Biogeosciences 112, 1-25. doi:10.1029/2006JG000293

Wilson, K.B., Baldocchi, D.D., 2000. Seasonal and interannual variability of energy fluxes over a broadleaved temperate deciduous forest in North America. Agric. For. Meteorol. 100, 118. doi:10.1016/S0168-1923(99)00088-X

Xia, J.Y., Luo, Y.Q., Wang, Y.P., Weng, E.S., Hararuk, O., 2012. A semi-analytical solution to accelerate spin-up of a coupled carbon and nitrogen land model to steady state. Geosci. Model Dev. 5, 1259-1271. doi:10.5194/gmd-5-1259-2012 
Xia, L., Wang, F., Mu, X., Jin, K., Sun, W., 2015. Water use efficiency of net primary production. J. Earth Syst. Sci. 124, 921-931. doi:10.1007/s12040-015-0587-4

Yang, Q., Tian, H., Friedrichs, M.A. M., Hopkinson, C.S., Lu, C., Najjar, R.G., 2015. Increased nitrogen export from eastern North America to the Atlantic Ocean due to climatic and anthropogenic changes during 1901-2008. J. Geophys. Res. Biogeosciences n/a-n/a. doi:10.1002/2014JG002763

Yang, X., Post, W.M., 2011. Phosphorus transformations as a function of pedogenesis: a synthesis of soil phosphorus data using Hedley fractionation method. Biogeosciences Discuss. 8, 5907-5934. doi:10.5194/bgd-8-5907-2011

Zan, C.S., Fyles, J.W., Girouard, P., Samson, R. A., 2001. Carbon sequestration in perennial bioenergy, annual corn and uncultivated systems in southern Quebec. Agric. Ecosyst. Environ. 86, 135-144. doi:10.1016/S0167-8809(00)00273-5

Zhang, X., Izaurralde, R.C., Arnold, J.G., Williams, J.R., Srinivasan, R., 2013. Modifying the Soil and Water Assessment Tool to simulate cropland carbon flux: Model development and initial evaluation. Sci. Total Environ. 463-464, 810-822. doi:10.1016/j.scitotenv.2013.06.056

Zhang, X., Izaurralde, R.C., Manowitz, D.H., Sahajpal, R., West, T.O., Thomson, A.M., Xu, M., Zhao, K., LeDuc, S.D., Williams, J.R., 2015. Regional scale cropland carbon budgets: Evaluating a geospatial agricultural modeling system using inventory data. Environ. Model. Softw. 63, 199-216. doi:10.1016/j.envsoft.2014.10.005

Zhao, M., Heinsch, F.A., Nemani, R.R., Running, S.W., 2005. Improvements of the MODIS terrestrial gross and net primary production global data set. Remote Sens. Environ. 95, 164176. doi:10.1016/j.rse.2004.12.011

Zhu, W., Pan, Y., He, H., Yu, D., Hu, H., 2006. Simulation of maximum light use efficiency for some typical vegetation types in China. Chinese Sci. Bull. 51, 457-463. doi:10.1007/s11434-006-0457-1 
Table1 The ten AmeriFlux sites selected for SWAT model performance evaluation

\begin{tabular}{|c|c|c|c|c|c|c|c|}
\hline Site & Abbreviation & State & Latitude & Longitude & Elevation $(\mathrm{m})$ & $\begin{array}{l}\text { Vegetation type (IGBP } \\
\text { Classification) }\end{array}$ & Reference \\
\hline Harvard Forest & US-Ha1 & MA & 42.5377 & -72.1714 & 340 & Deciduous Broad-leaf Forest & Urbanski et al. (2007) \\
\hline $\begin{array}{l}\text { Howland Forest } \\
\text { Main }\end{array}$ & US-Ho1 & ME & 45.2041 & -68.7402 & 60 & Evergreen Needle-leaf Forest & $\begin{array}{l}\text { Richardson et al. } \\
\text { (2009) }\end{array}$ \\
\hline Missouri Ozark & US-MOz & MO & 38.7441 & -92.2000 & 219 & Deciduous Broad-leaf Forest & $\begin{array}{l}\text { Gu et al. }(2006,2012 \text {, } \\
2015)\end{array}$ \\
\hline $\begin{array}{l}\text { Morgan Monroe } \\
\text { State Forest }\end{array}$ & US-MMS & IN & 39.3231 & -86.4131 & 275 & Deciduous Broad-leaf Forest & Schmid et al. (2000) \\
\hline $\begin{array}{l}\text { Sylvania } \\
\text { Wilderness }\end{array}$ & US-Syv & MI & 46.2420 & -89.3477 & 540 & Mixed Forest & Desai et al. (2005) \\
\hline UMBS & US-UMB & MI & 45.5598 & -84.7138 & 234 & Deciduous Broad-leaf Forest & Gough et al. (2013) \\
\hline Walker Branch & US-WBW & $\mathrm{TN}$ & 35.9588 & -84.2874 & 343 & Deciduous Broad-leaf Forest & $\begin{array}{l}\text { Wilson and } \\
\text { Baldocchi (2000) }\end{array}$ \\
\hline Willow Creek & US-WCr & WI & 45.8059 & -90.0799 & 515 & Deciduous Broad-leaf Forest & Cook et al. (2004) \\
\hline Park Falls & US-PFa & WI & 45.9459 & -90.2723 & 470 & Mixed Forest & Davis et al. (2003) \\
\hline Niwot Ridge & US-NR1 & $\mathrm{CO}$ & 40.0329 & -105.5464 & 3050 & Evergreen Needle-leaf Forest & $\begin{array}{l}\text { Monson and } \\
\text { Turnipseed, (2002) }\end{array}$ \\
\hline
\end{tabular}


Table 2 Key parameters of SWAT carbon cycling simulation and corresponding values in the default and improved simulations

\begin{tabular}{|c|c|c|c|c|c|c|c|c|}
\hline \multirow[t]{2}{*}{ Parameter } & \multirow[t]{2}{*}{ Name } & \multirow[t]{2}{*}{ Unit } & \multicolumn{3}{|c|}{$\begin{array}{c}\text { Default } \\
\text { values }\end{array}$} & \multicolumn{3}{|c|}{$\begin{array}{c}\text { Calibrated } \\
\text { values }\end{array}$} \\
\hline & & & FRST & FRSD & FRSE & FRST & FRSD & FRSE \\
\hline$B I O \_E$ & $\begin{array}{l}\text { Radiation use } \\
\text { efficiency }\end{array}$ & $\begin{array}{l}\text { kg biomass } \\
/ \mathrm{ha} /\left(\mathrm{MJ} / \mathrm{m}^{2}\right)\end{array}$ & 15 & 15 & 15 & $\begin{array}{l}24-27 \\
(25.5)^{*}\end{array}$ & $\begin{array}{l}26-30 \\
(28.2) *\end{array}$ & $\begin{array}{l}16-18 \\
(17)^{*}\end{array}$ \\
\hline$B L A I$ & $\begin{array}{l}\text { Maximum } \\
\text { Leaf area index }\end{array}$ & unitless & 5 & 5 & 5 & $\begin{array}{l}4-5 \\
(4.5)^{*}\end{array}$ & $\begin{array}{l}4-5 \\
(4.6) *\end{array}$ & $\begin{array}{l}3-4 \\
(3.5) *\end{array}$ \\
\hline$T \_O P T$ & $\begin{array}{l}\text { Optimum } \\
\text { temperature }\end{array}$ & Degree $\left({ }^{\circ} \mathrm{C}\right)$ & 30 & 30 & 30 & $\begin{array}{l}25 \\
(25)^{*}\end{array}$ & $\begin{array}{l}23-25 \\
(24)^{*}\end{array}$ & $\begin{array}{l}20-25 \\
(22.5) *\end{array}$ \\
\hline$T \_B A S E$ & Base temperature & Degree $\left({ }^{\circ} \mathrm{C}\right)$ & 10 & 10 & 0 & $\begin{array}{l}10 \\
(10) *\end{array}$ & $\begin{array}{l}10 \\
(10)^{*}\end{array}$ & $\begin{array}{l}0-5 \\
(2.5) *\end{array}$ \\
\hline BIO_LEAF & $\begin{array}{l}\text { Leaf to biomass } \\
\text { fraction }\end{array}$ & unitless & 0.3 & 0.3 & 0.3 & $\begin{array}{l}0.02-0.05 \\
(0.035)^{*}\end{array}$ & $\begin{array}{l}0.02-0.06 \\
(0.033) *\end{array}$ & $\begin{array}{l}0.015-0.025 \\
(0.02)^{*}\end{array}$ \\
\hline
\end{tabular}

Note: FRST: mixed forest; FRSD: deciduous forest; FRSE: evergreen forest; $*$ indicates average values. 


\section{Figures}

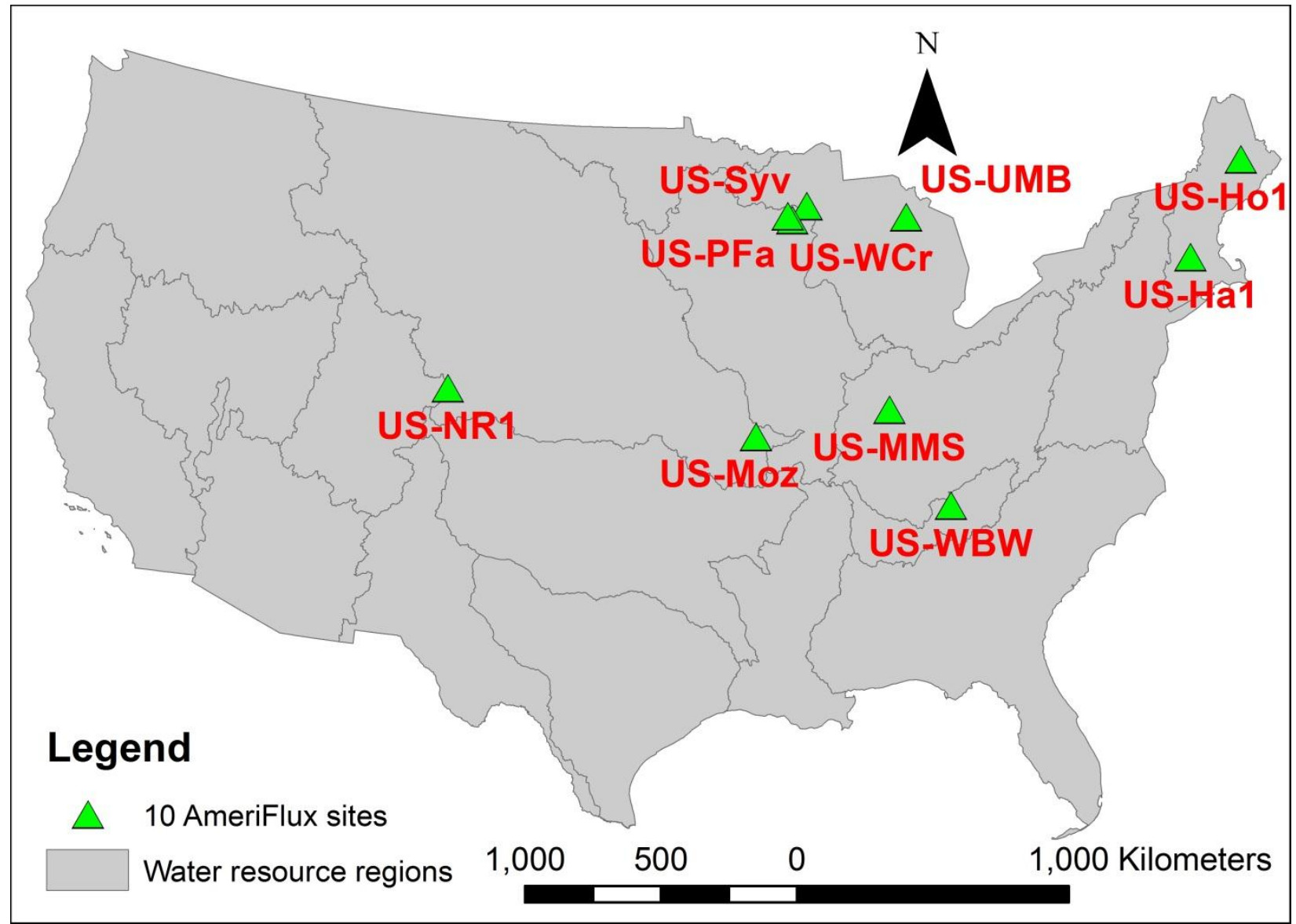

Fig. 1. Locations of ten AmeriFlux sites selected for model performance evaluation (US-Ha: Harvard Forest; US-Ho1: Howland Forest Main; US-MMS: Morgan Monroe State Forest; US-

Syv: Sylvania Wilderness; US-UMB: UMBS; US-WCr: Willow Creek forest; US-MOz: Missouri Ozark: US-WBW: Walker Branch; US-NR1: Niwot Ridge; US-PFa: Park Falls) 


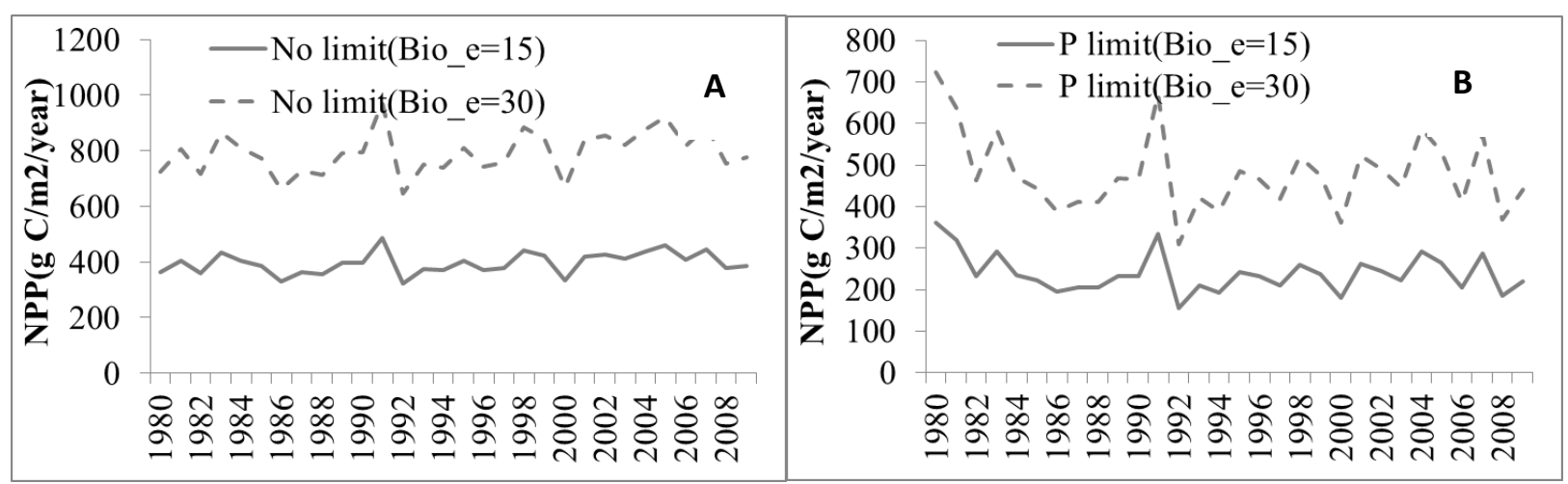

Fig. 2. Model simulation experiments with the default parameterization at the Harvard Forest site to show the impacts of radiation use efficiency (Bio_e) and phosphorus (P) supply on NPP estimates (simulated NPP at two radiation use efficiency levels (A) without any environmental limits; (B) with limit from phosphorus). 


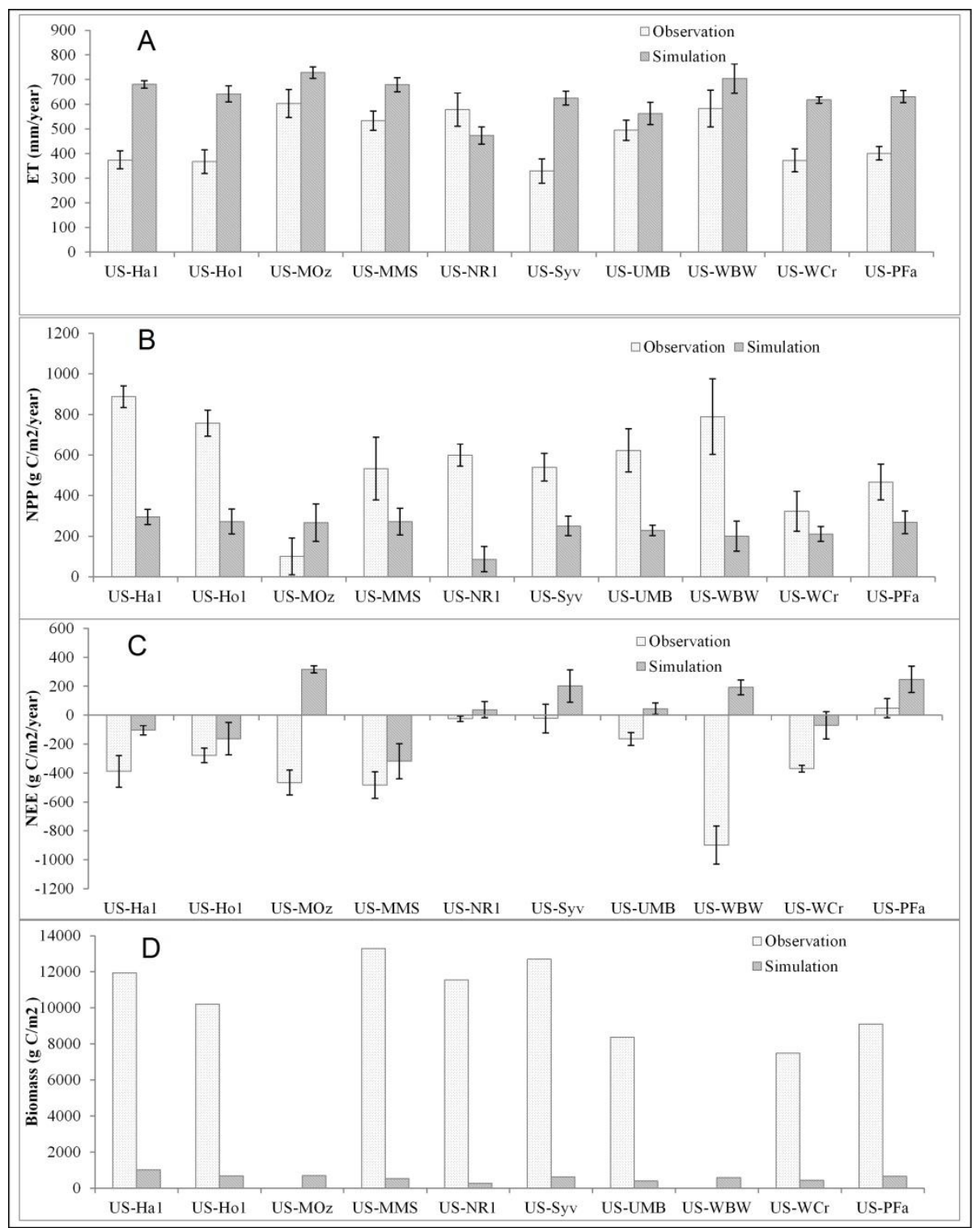

Fig. 3. Comparison of default SWAT simulation of (A) ET, (B) NPP, (C) NEE, (D) biomass with observations over ten AmeriFlux sites (US-Ha: Harvard Forest; US-Ho1: Howland Forest Main; US-MMS: Morgan Monroe State Forest; US-Syv: Sylvania Wilderness; US-UMB: UMBS; USWCr: Willow Creek forest; US-MOz: Missouri Ozark: US-WBW: Walker Branch; US-NR1:

Niwot Ridge; US-PFa: Park Falls) 


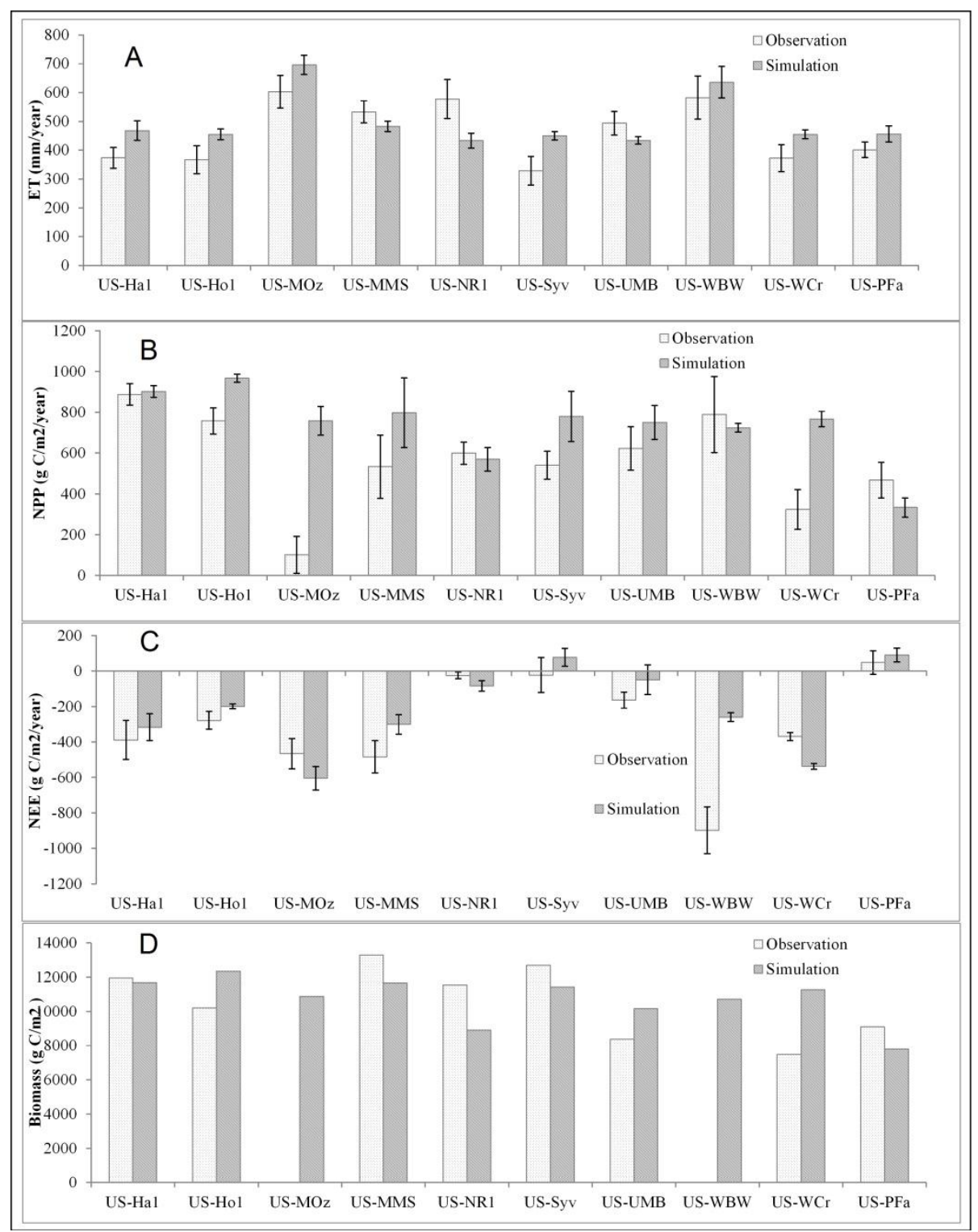

Fig. 4. Comparison of SWAT simulation of (A) ET, (B) NPP, (C) NEE, (D) biomass with observations over ten AmeriFlux sites using the improved parameterization (US-Ha: Harvard Forest; US-Ho1: Howland Forest Main; US-MMS: Morgan Monroe State Forest; US-Syv: Sylvania Wilderness; US-UMB: UMBS; US-WCr: Willow Creek forest; US-MOz: Missouri Ozark: US-WBW: Walker Branch) 


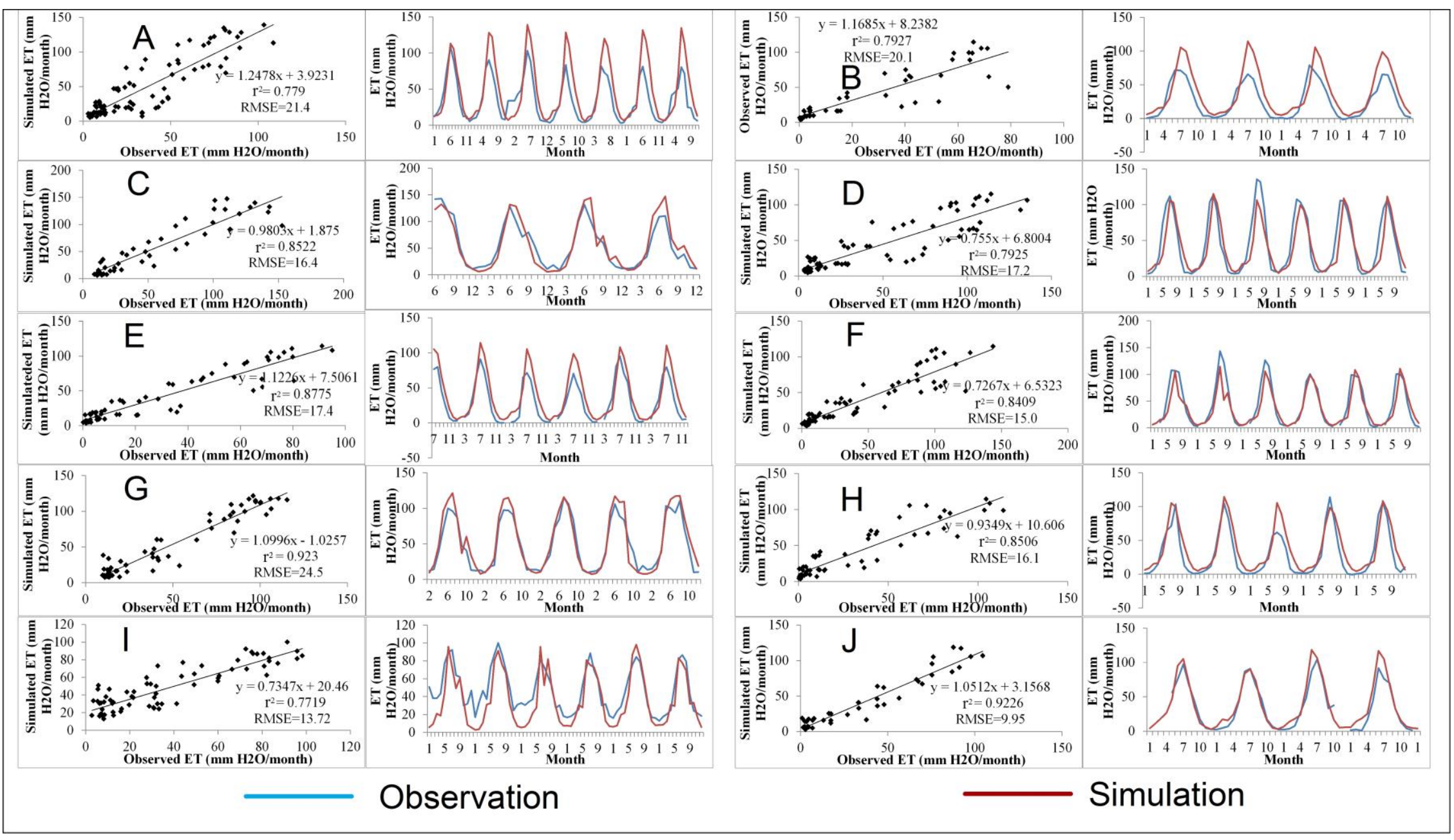

Fig. 5. Comparison of simulated ET with observation after improving nutrient inputs and parameterization (A: Harvard Forest; B: Howland Forest Main; C: Missouri Ozark; D: Morgan Monroe State Forest; E: Sylvania Wilderness Forest; F: UMBS; G: Walker Branch; H: Willow Creek Forest; I: Niwot Ridge; J: Park Falls) 


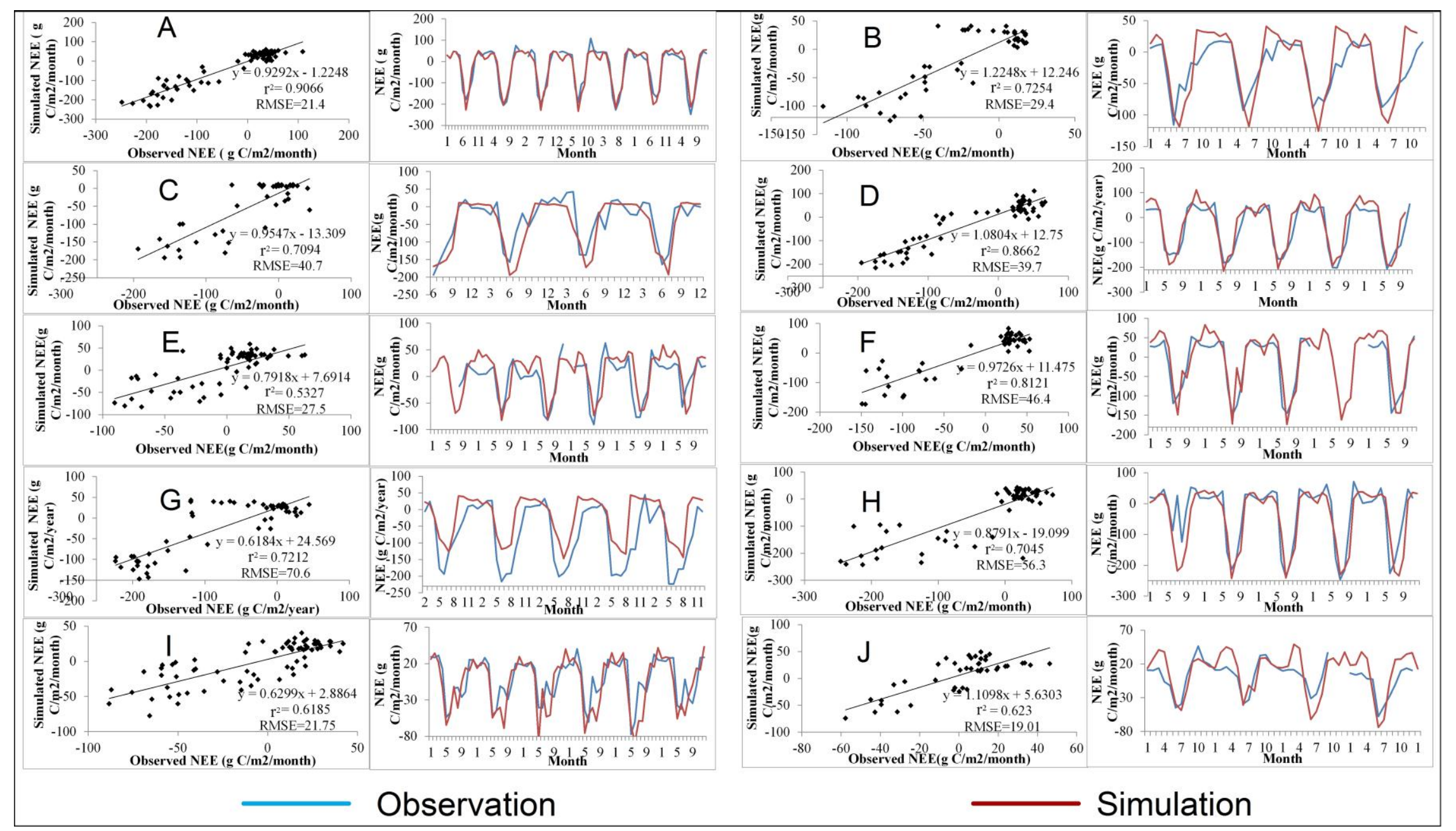

Fig. 6. Comparison of simulated NEE with observation after improving nutrient inputs and parameterization (A: Harvard Forest; B: Howland Forest Main; C: Missouri Ozark; D: Morgan Monroe State Forest; E: Sylvania Wilderness Forest; F: UMBS; G: Walker Branch; H: Willow Creek Forest; I: Niwot Ridge; J: Park Falls) 


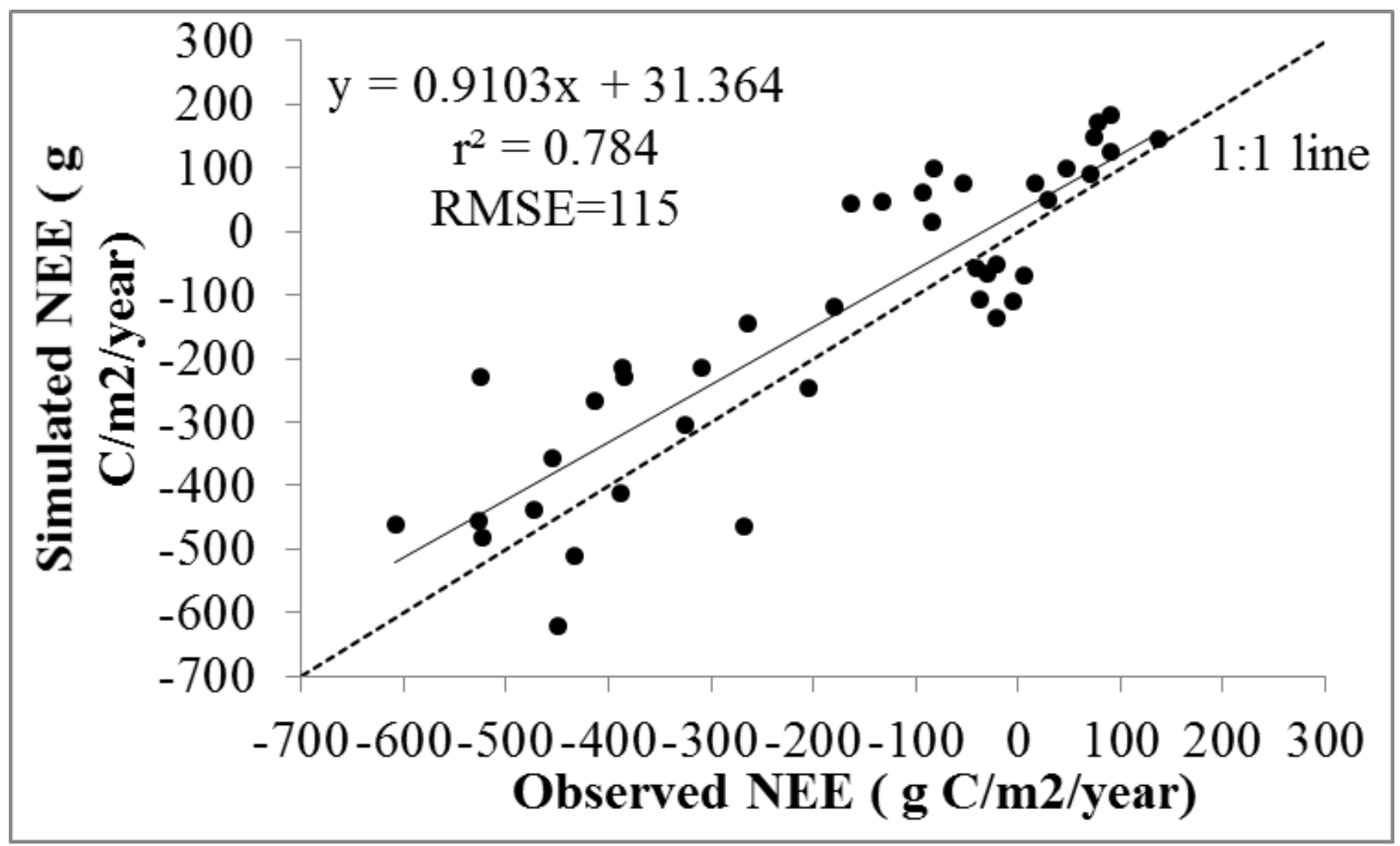

Fig. 7. Scatter plot of simulated and observed annual NEE across ten AmeriFlux sites (unit of RMSE is $\mathrm{g} \mathrm{C} / \mathrm{m}^{2} / \mathrm{year}$ ) 